\title{
Determinants of financial reporting quality: Evidence from Indonesia
}

\author{
Soni Agus Irwandi \\ Accounting Study Program, \\ STIE Perbanas, Indonesia \\ soni_inwandi@perbanas.ac.id \\ Imang Dapit Pamungkas \\ Faculty of Economics and Business, \\ Dian Nuswantoro University, Indonesia \\ Imangdapit.pamungkas@dsn.dinus.ac.id
}

Abstract. This research aims to investigate the determinants of financial reporting quality, which is a very complex issue in the manufacturing industry and a significant contributor to a company's finance. This research is therefore aimed to examine the effect of litigation risk, investor's distrust, and legal expertise of the audit committee. The data were obtained from the annual reports of the manufacturing companies listed at the Indonesia Stock Exchange during 20152018. The research sample consists of 287 public companies, with moderated regression analysis used to examine the hypotheses. The results show that the risk of investor distrust affects financial reporting quality, while legal expertise of the audit committee is a moderating variable that strengthens the relationship between the risk of investor distrust and financial reporting quality.

Keywords: litigation risk, investor distrust, legal expertise, financial reporting quality, Indonesia Stock Exchange.

JEL Classification: G30, G32, M41

\section{INTRODUCTION}

Information irregularities are reduced in companies through improved financial reports (Chen et al., 2011). However, based on the agency theory, many factors tends to weaken manager's ability to obtain relevant information for better supervision of managerial activities (Gomariz \& Balesta, 2014). Accounting case, which had occurred in the last decade in Indonesia, and this research to investigate the determinants of financial reporting quality. Ahmed (2007) and Mendes et al. (2012) stated that the general purpose of issuing financial reports is to provide information concerning fiscal budget, performance, and cash flow. According to Krishnan (2011), financial reporting quality is one of the important contributors to company's 
information. Generally, its purpose is to provide useful information for the decision-making process. However, companies tend to produce their financial statements using different types of accounting principles (Choi \& Pae, 2011). Chen et al. (2011) stated that high-quality accounting information is a valuable method used to counteract information asymmetry.

According to Choi and Pae, (2011), quality financial report is are very important for the company. Therefore, differences in managerial reports lead to conflict between managers and shareholders due to the emergence of information asymmetry. This also gives rise to errors, thereby leading to litigation, which is one of the external factors that hinder managers in carrying out their duties. Juanda (2006) stated that investors and creditors need to file lawsuits against companies when fighting for their rights and interests. Litigation occurs when the existing legal and regulatory practice does not include accounting practices and also arises due to not transparent information by the operational management. Chrisnoventie (2012) stated that litigation risk is an inherent uncertainty in a company due to stakeholder can harm the company. Management behavior is also affected by the risks associated with litigation which makes management seek for the ways to convince the funder to continue investing in the company. This is often achieved by polishing the reports produced by the company to appear good to the reader which ultimately leads to manipulations with accounting data and information. Litigation risk is an external factor, so managers tend to avoid the possibility of litigation risks that harm the company. It tends to occur when accounting practices conducted by a company go against the existing laws and regulations (Juanda, 2006). With the success of managers to avoid litigation risk, investors' interests will eventually be protected and investors can develop stock markets, equity, ownership structures, and dividend policies (Leuz et al., 2002; Hodge 2013). When investors buy stock, they automatically obtain certainty of right or obligation that is protected by the law.

Furthermore, quality financial report is strongly speculated to be one of the causes of investor distrust at a weak stock market. Its risk is associated with the inability to gain access to the information concerning the market situation, investee condition, and debts (Knechel \& Salterio, 2016). Quality of financial information is influenced by the risk of the company's failure to obtain profits from creditors in the form of debt (Veliandina, 2013). Financial reporting aims to provide quality financial information as a consideration for stakeholders (investors and creditors) as a source of corporate funding.

Although the Regulation of the Bank of Indonesia No. 8/4/PBI/2006 regarding the Establishment of Good Corporate Governance stated that members of audit committees needs to have expertise in law and banking, this is not the situation with manufacturing companies in Indonesia, which tends to be not mandatory. Suaryana (2005), Krishnan (2011), Laux et al. (2011), and Hodge (2013) explained that the audit committee with a law background tends to encourage its members to be careful in avoiding litigation factors and this might reduce the quality of reporting. Chen et al. (2011) stated that financial reporting quality affected the efficiency of investment in private companies in developing countries.

This study contributes to investigation of various risk models and law expertise of audit committees. It identifies, evaluates and analyzes the risks related to financial reporting. It also aims to examine the law expertise of audit committees as a moderating variable between litigation risk and investor distrust.

\section{LITERATURE REVIEW}

\subsection{Agency theory}

Scott (2012) defined this theory as a working relationship between the manager and the stockholder, which provides capital to the company. The connection between this theory and research is related to litigation risk and investor protection because the company tends to cover information on low investor protection. It also strives not to lose funds by providing attractive financial reports which motivate the 
investor. This is achieved by ensuring that the reported information is in accordance with the real condition of the company.

\subsection{Financial reporting quality}

Financial reporting quality is a report presented based on the company's condition, which decreases due to the funder's ability to understand accounting. Excellent financial reporting quality reduces information asymmetry between the principal and agent in accordance with the company's legal obligations (Landsman et al. 2012). When an error occurs during the reporting process, the legal committee's audit trustees correct it immediately to avoid creating problems for the company. The audit committees also possess the same professional capabilities as corporate lawyers and tend to communicate effectively with them in resolving problems that have legal implications. According to Akgun et al. (2017), producing proficient financial reports raises the standard of employees responsible for preparing monetary statements. The employee involved in the activity needs to understand how the process and practice of accounting are run based on the rules of the company. Therefore, quality financial statements prevent the company from encountering a condition in which the investment is lower and serves as a tool for determining future fiscal policies. In this study, the quality of financial statements was measured using the real earnings model (Asti, 2014).

\subsection{Litigation risk on financial reporting quality}

Litigation occurs because accounting practices carried out by the company are not performed by the existing legal and regulatory provisions. It also arises as a result of hidden negative information with a potential legal risk embedded to mislead the consumers. Management cover or hide such information from interested parties it also strives to produce reports that make these parties continue to believe and be interested in the company. The management revised reports to make it appear useful to the stakeholders for the continuous injection of funds into the company. However, this worsens the report worse because the information displayed does not show the actual situation, rather it appears to be manipulated. Reports need to be in perfect condition, which is the basis of decision making, for the company to continue acquiring capitals for its operations. When the information reported appears to be too real, the management becomes concerned that the parties might not be interested in the company and does not inject funds, which leads to failure in the operation of the establishment. Management as a company agent certainly does not want this to happen, especially when the compensation given is assessed based on the results of its performance. It strives for the company to continue operation and generate profits that serve as returns for the principal. Laux and Stocken (2011) also stated that the greater the expected legal penalties faced by companies, the more the management tends to be aware of their reports.

Litigation is the process whereby an individual or entity brings a dispute or case to the court for settlement of claims or replacement of damages (Juanda, 2006, Chen, 2009, Dechow, 2010, and Laux et al., 2011. Lawsuits and litigation tend to arise when the financial statements do not correspond to the actual conditions of the company, which is detrimental to the parties concerned. Litigation risk is higher once there is a decline in the quality of financial reporting (Juanda, 2006). Laux and Stocken (2011) also mentioned that the greater the expected legal penalties faced by companies, the more the management prevent it from reporting, and leading to increased misreporting. Therefore, from the above ideas, it is deduced that high litigation risk of a company results in poor financial reporting quality. Jackson et al. (2015), Cao et al. (2011), and Boone et al. (2011) established that it significantly influence financial reporting quality and help companies' objectives to be achieved by supervising the activities that caused the low-quality financial reporting. Therefore, the following hypothesis was formulated: 
$\mathrm{H}_{1}:$ Litigation risk affects financial reporting quality.

\subsection{Risk of investor distrust on financial reporting quality}

The official protection of external investors is identified as a critical determinant in the development of financial markets, capital/ownership structure, and dividend policy (Anggraeni, 2010). Stocks purchased by investors, their rights are protected by laws and regulations. This tends to be weak in accordance with uncertain conditions and investor distrust. Therefore, the high risk of investor distrust leads to poor quality financial statements. Hodge (2013); Anggraini et al., (2010); Cahan et al., (2008); Ahmed et al.,(2007) stated that investor distrust affects the financial reporting quality which occurs when certain authorities, inhibit information without clarity from regulators. Companies tend to experience declines in financial reporting quality, therefore, the essence of investor protection is to encourage shareholders to invest in the capital market with promising positions, especially in terms of obtaining access to information on the market situation (Knechel and Salterio (2016).

$\mathrm{H}_{2}$ :Risk of investor distrust affects financial reporting quality

\subsection{Default risk on financial reporting quality}

This research refers to prior studies conducted by Mehdi et al. (2010), Zamri et al. (2013), and Veliandina (2013), which measured the amount of default risk (the risk of company failure) by the level of leverage a company posses. Financial leverage is calculated by the ratio of debt to the total capital of the company. The results from previous studies show that the default risk negatively affects the quality of financial statements. The default risk on the amount of debt owed by a company greatly affects its performance. Therefore, when the default risk is high, the quality of the company's financial statement that was captured by investors decreases, while the management tends to utilize its earnings.

$\mathrm{H}_{3}$ :Default risk affects financial reporting quality

\subsection{Relationship between litigation risk, risk of investor distrust, default risk, and audit committee legal expertise with financial reporting quality}

Audit committees with legal backgrounds make other members be more careful on the increased risk of litigation, which reduces the reporting quality. Legal expertise of audit committees reduces litigation risk by providing warnings and corrective measures that tend to result in legal problems. According to Krishnan et al. (2011), in recent years, there has been a significant increase in the number of legal experts appointed as company boards. Krishnan et al. conducted a study in 2011 concerning the relationship between audit committee legal expertise and financial reporting quality and discovered that the audit committee with a legal background made a positive contribution to the quality of the company's financial reporting. It has been observed that the number of legal experts appointed as the board of companies has increased in recent years, especially after the issuance of the Sarbanes Oxley Act 2002. The existence of an audit committee legal expert helps to oversee the financial reporting process and ensures that management functions effectively in order to avoid litigation threats. The Bank of Indonesia regulations stated that at least one audit committee member needs to possess knowledge of law or banking.

By Bapepam regulation, an audit committee consists of at least three (3) members that are mostly independent directors, representatives of external party issuers and public companies. At least one of the members needs to possess educational background and expertise in the field of accounting or finance. Furthermore, the Bank of Indonesia Regulation No. 8/4/PBI/2006 on Implementation of Good Corporate Governance for Banks stated that one of the members of the audit committee needs to possess expertise in 
law or banking. The litigation, investor distrust, and default risks are expected to strengthen its relationship with the financial reporting quality by an audit committee with a law background. The research conducted by Suaryana (2005), Krishnan (2011), Laux et al. (2011), and Hodge (2013) stated that the audit committee with competent legal knowledge are wary of risk possibilities that degrades the quality of reports. Litigation risk, and investor distrust, leads to low quality report. The existence of legal experts on the audit committee reduces the effect of litigation risk on the quality of corporate financial reporting. The theoretical Framework in this study is presented in figure 1. Based on the above idea, the following hypothesis was deduced as follows:

$\mathrm{H}_{4}$ :The existence of the audit committee's legal expertise strengthens the relationship between litigation risk, risk of investor distrust, default risk, and quality of corporate financial reporting.

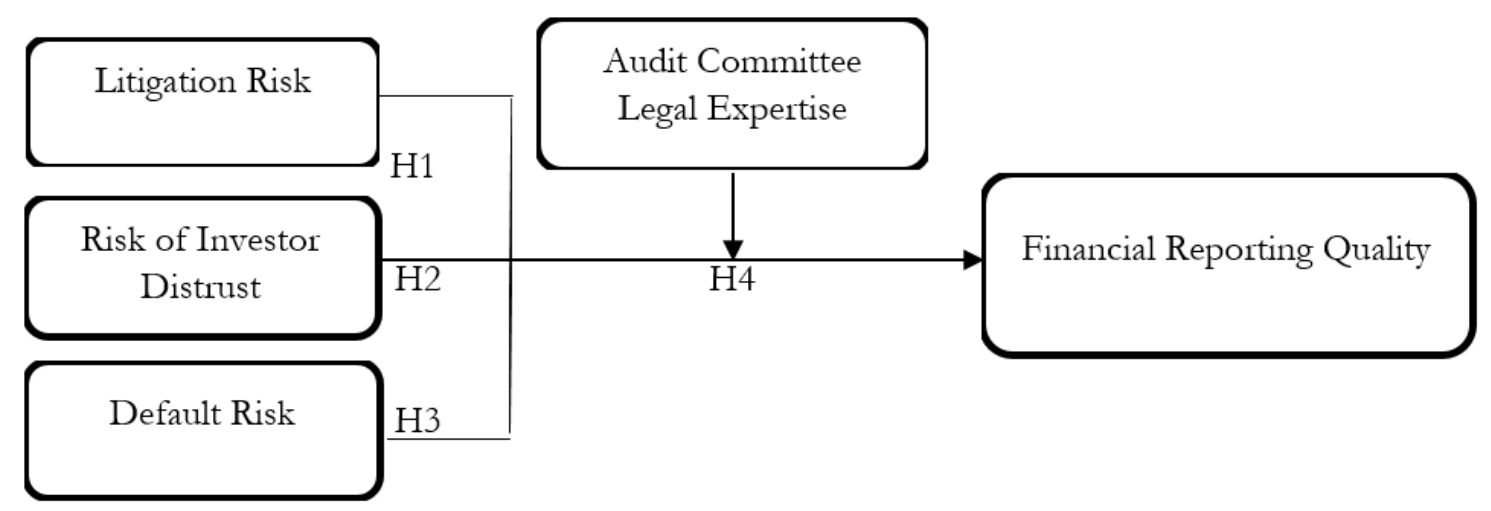

Figure 1. Theoretical framework

\section{METHODOLOGY}

Secondary data was used in the form of annual reports and summary of performance of 287 public companies listed in the Indonesia Stock Exchange from 2015-2018 as presented in Table 1.

Table 1

Number of Study Samples

\begin{tabular}{|l|c|}
\hline \multicolumn{1}{|c|}{ Criteria } & Number of Samples \\
\hline Total population & 555 \\
\hline The company carries out business activities related to the manufacturing sector & 555 \\
\hline $\begin{array}{l}\text { The company is listed BEI period 2015-2017 and is continuously conducting financial } \\
\text { reporting }\end{array}$ & 409 \\
\hline The company conducts financial reporting that has gone through the audit process & 390 \\
\hline The company has submitted complete data on financial ratios & 287 \\
\hline Number of Samples Obtained (3 years) & 287 \\
\hline
\end{tabular}

Source: Secondary data processing, 2019

The data obtained were analyzed using the regression analysis, with the dependent variable as the financial reporting quality (Ghozali, 2012). The Financial reporting quality was measured using real earning management, which was combined with three proxies, the abnormal operations cash flow (CFO), the abnormal production costs (PROD), and the abnormal discretionary expenses (DISCR) (Roychowdhury, 2006). Litigation risk in this study was conducted through the analysis of the following variables, stock 
returns and turnover volume of stock, both of which are a proxy for volatility, liquidity, and solvency. They are also a substitute for financial risk, while the size of the company is a proxy for political risk. This analysis summarizes the information contained in the initial variables into a new set of dimensions or factors. The variable is synthesized by factor analysis in order to determine the litigation risk index. A high index value indicates an enormous litigation risk and vice versa. The risk of investor distrust used in this research is the investor protection index issued by the World Bank in 2019.

Investor protection is expressed in the strength of the Investor Protection Index (IPI), which is the average index of disclosure, director liability, and shareholder suits indexes. Conversely, using the default risk on a small investment generates a presumable advantage, however, it tends to experience a drastic loss assuming the correct risk management is not applied. In this study, the default risk is measured by the financial leverage ratio, which compares the total debt to the total assets of the company. The moderating variable of this study is the legal expertise of the audit committee. Asti (2014) discovered that companies that have an effective audit committee hardly report back (restatement) quarterly profit. Krishnan et al. (2011) defined legal expertise as someone who has an educational background in law or has working experience as a jurist, such as an attorney or lawyer. The legal expert of an audit committee is measured by its proportion, which is the number of its lawyers divided by the total number of the audit committees (Krishnan et al., 2011).

\section{EMPIRICAL RESULTS AND DISCUSSION}

The first hypothesis test on Table 2 , showed a significance value of 0.288 , therefore, litigation risk does not affect financial reporting quality. This means that the size of the litigation risk does not affect the company's non-discretionary accruals policy, which tends to have an impact on the quality of financial statements. The high value of discretionary accruals indicated this. The result of this study does not agree with the research of Kartika and Nahumury (2014), which stated that litigation risk has a significant effect on earnings management. The weak corporate governance leads to the view that investors and creditors are the parties with weaker legal protection. Therefore, these categories of investors, feel the legal guarantees granted by the regulator, which is supposed to protect their interest, are increasingly weak. This causes the strength of litigation risk attached to the company on the Indonesia Stock Exchange not to affect the financial reporting quality.

Table 2

Hypothesis Test Result

\begin{tabular}{|l|c|c|c|}
\hline Path & $\begin{array}{c}\text { Direct Effect } \\
\text { Coefficient }\end{array}$ & p-value & Result \\
\hline Litigation risk $\square$ Financial Reporting Quality & -039 & 0,288 & H1 Rejected \\
\hline Risk of Investor distrust $\square$ Financial Reporting Quality & -695 & $0,001^{* *}$ & H2 Accepted \\
\hline Default risk $\square$ Financial Reporting Quality & -.002 & 0,972 & H3 Rejected \\
\hline $\begin{array}{l}\text { Litigation risk, Risk of Investor distrust, Default risk*Legal } \\
\text { expert of the audit committee } \square \text { Financial Reporting Quality }\end{array}$ & 177 & $0,016^{* *}$ & H4 Accepted \\
\hline
\end{tabular}

Source: MRA Processing Results, 2019

* indicates significance level at 0.10 level, ** indicates significance level at 0.05 level, $* * *$ indicates significance level at 0.01 level.

The second hypothesis showed a significance value of 0.001 , therefore, risk of investor distrust expressed in the Strength of Investor Protection Index (IPI) by the world bank in 2014 affected financial 
reporting quality. The results are consistent with research conducted by Jere (2008). Anggraeni (2010) suggested that the risk of investor distrust affects the quality of financial information when companies adopt the IFRS. Houqe et al. (2012) also agreed with the results of this study, which suggests that the risk of investor distrust affects the quality of financial information of the company. Subsequent supervision by the independent board of commissioners discourages the manipulation of financial statements, thereby, making it more appropriate.

The risk of investor distrust affects the quality of financial statements of companies listed on the Indonesian Stock Exchange. This is also due to the high risk of investor distrust in the company. It implies that the financial statements' information keeps declining. Therefore, the company has to seriously maintain the conditions of trust and protection for investors as well as ensure that high-quality information on financial statements is presented in order to reduce the risk of investor distrust. The high risk of investor distrust reduces the number of earnings management (Cahan, 2008). Furthermore, the existence and function of the independent board have been fully implemented.

The results from testing the third hypothesis indicate that the significance value is 0.972 . The third hypothesis test results showed that the default risk, as measured by the leverage in this study, did not affect the quality of financial information. It also indicated that leverages selected alternative funding because they have higher information irregularities. The greater the ratio of debt to assets, the higher the market valuation of the company. Investors tend to respond positively to the added value of companies because of the leverages. Information regarding changes in financial leverage tends to provide facts concerning the economy of the company and risk that has a relevance value for investors. The results from this study support the pecking order theory (Myers, 1984), which stated that leverage did not significantly influence the value of the company. The results are consistent with the research conducted by Rafiee et al. (2014). Therefore, assuming there is an increase in earnings, debt holders tend to benefit, however, the better the condition of corporate profits, the more negative the response of the shareholders tend to be because they feel that only creditors gain (Veliandina, 2013).

Based on Table 2, the fourth hypothesis showed that the audit committee's legal expertise in this study does affect the quality of financial statements. The result of this study is in accordance with the research conducted by Jeffrey et al. (2014) stated that in carrying out duties, members of the audit committee who have knowledge of law or legal aspects need to conduct the management to refrain from policies that tend to degrade the quality of financial statements. The board of directors needs to be independent in making decisions to avoid deterioration which is caused by the audit committee.

Table 3

Model Summary

\begin{tabular}{|c|c|c|c|c|}
\hline Model & $\mathrm{R}$ & $\mathrm{R}$ Square & Adjusted R Square & Std. The error of the Estimate \\
\hline 1 & $.849^{\mathrm{a}}$ & .722 & .717 & .111235455 \\
\hline
\end{tabular}

a. Predictors: (Constant), X1, X2, X3, X4

Source: MRA Processing Results, 2019

The results also showed that the audit committee's legal expertise as a moderating variable strengthens the relationships between the risk of investor distrust and financial reporting quality Table 3. Model Summary explained that the value of $\mathrm{R}$ Square equals 0.722 , this concludes that Litigation Risk, Risk of Investor Distrust, Default Risk, and Audit Committee Legal Expertise simultaneously affects financial reporting quality by $72,2 \%$. This study encourages the regulators in Indonesia to monitor the need for an audit committee's legal expertise to guarantee investor trust in the quality of financial information. 
The existence of an audit committee within a company offers supervision of management performance and provides accurate information on company reporting. One factor that affects the performance of corporate audit committees is the competence of the company's audit committee. Audit committees members with backgrounds in the field of law tend to be more careful with company activities that have legal implications in order to improve the financial reporting quality. The financial reporting quality is also related to the possibility of the emergence of legal obligations for the company. With the existence of a legal background, the audit committee causes the management to become aware of the possibility of this obligation. When an error occurs during the reporting process, the audit committee with legal expertise find it necessary to immediately it to avoid legal problems which are detrimental to the company's reputation. The audit committees also possess same professional capabilities as corporate lawyers and communicate better with company attorneys in order to resolve problems with legal implications. This is in line with the research conducted by Krishnan et al. (2011), which stated that a positive relationship exists between the audit committee's legal background and financial reporting quality. The existence of an audit committee with legal experts in the company reduces the impact of risk mitigation on its financial reporting.

\section{CONCLUSION}

This study enables the proper regulation of rules for better legal protection for investors. Partial test showed that the risk of investor distrust affects the financial reporting quality and acts as a moderating variable that strengthens investor distrust. This study encourages regulators in Indonesia to ensure investors are confident and trust the quality of the financial reporting.

Furthermore, it explains the role of the audit committee, in professional organizations like the Indonesian capital investment supervision agency, to ensure that regulations are formulated to protect the interests of investors. The next researcher is expected to expand the study sample and consider the implementation of good corporate governance variables to determine proper legal protection for investors.

\section{REFERENCES}

Ahmed, A. S., \& Duellman, S. (2007). Accounting conservatism and board of director characteristics: An empirical analysis. Journal of accounting and economics, 43(2-3), 411-437.

Akgun, A. İ. (2017). Evaluasi Provisi untuk Provisi untuk Provisi untuk Provisi untuk Kebangkrutan dalam Penundaan Kebangkrutan. Jurnal Ilmu Politik, Ekonomi dan Manajemen, 5 (3).

Anggraini, F. R. R., Nurim, Y., \& Harjanto, N. (2010). Pengujian Peran Perlindungan Investor dan Kultur terhadap Perilaku Managemen Laba pada Perusahaan Keluarga: Studi Internasional. Simposium Nasional Akuntansi XIII.

Awalia, A., \& Daljono, D. (2014). Pengarub Risiko Litigasi terhadap Kualitas Pelaporan Kenangan dengan Keablian Hukum Komite Audit sebagai V ariabel Pemoderasi (Studipada Perusabaan manufakturyang Terdaftar di Bursa Efek Indonesia periode 2010-2012) (Doctoral dissertation, Fakultas Ekonomika dan Bisnis).

Cahan, S. F., Liu, G., \& Sun, J. (2008). Investor protection, income smoothing, and earnings informativeness. Journal of International Accounting Research, 7(1), 1-24.

Chen, S., Wang, Y., \& Zhao, Z. (2009). Regulatory incentives for earnings management through asset impairment reversals in China. Journal of Accounting, Auditing \& Finance, 24(4), 589-620.

Choi, T. H., \& Pae, J. (2011). Business ethics and financial reporting quality: Evidence from Korea. Journal of Business Ethics, 103(3), 403-427.

Chrisnoventie, D., \& Raharja, S. (2012). Pengaruh ukuran KAP dan spesialisasi industri KAP terhadap kualitas audit: tingkat risiko litigasi perusahaan sebagai variabel moderasi. Journal of Accounting, 1(1).

Cohen, J. R., Hoitash, U., Krishnamoorthy, G., \& Wright, A. M. (2013). The effect of audit committee industry expertise on monitoring the financial reporting process. The Accounting Review, 89(1), 243-273. 
Dechow, P., Ge, W., \& Schrand, C. (2010). Understanding earnings quality: A review of the proxies, their determinants, and their consequences. Journal of accounting and economics, 50(2-3), 344-401.

Francis, J. R., \& Wang, D. (2008). The joint effect of investor protection and Big 4 audits on earnings quality around the world. Contemporary accounting research, 25(1), 157-191.

Ghozali, I. (2012). Metode Penelitian Kuantitatif. Bandung: Alfabeta.

Hodge, F. D. (2003). Investors' perceptions of earnings quality, auditor independence, and the usefulness of audited financial information. Accounting Horizons, 17, 37-48.

Houqe, M. N., van Zijl, T., Dunstan, K., \& Karim, A. W. (2012). The effect of IFRS adoption and investor protection on earnings quality around the world. The International Journal of accounting, 47(3), 333-355.

Juanda, A. (2006). Pengarub Risiko Litigasi Dan Tipe Strategi Terbadap Hubungan Antara Konflik. Kepentingan Dan Konservatisma Akuntansi (Doctoral dissertation, Universitas Gadjah Mada).

Kartika, T. P. D., \& Nahumury, J. (2014). The effect of litigation risks to earnings management using audit quality as a moderating variable. Journal of Economics, Business \& Accountancy Ventura, 17(2), 303-312.

Knechel, W. R., \& Salterio, S. E. (2016). Auditing: Assurance and risk. Routledge.

Krishnan, C. N. V., Masulis, R., Thomas, R. S., \& Thompson, R. B. (2011). Litigation in mergers and acquisitions. Available at SSRN 1443384.

Landsman, W. R., Maydew, E. L., \& Thornock, J. R. (2012). The information content of annual earnings announcements and the mandatory adoption of IFRS. Journal of accounting and economics, 53(1-2), 34-54.

Leuz, C. (2003). IAS versus US GAAP: information asymmetry-based evidence from Germany's new market. Journal of accounting research, 41(3), 445-472.

Laux, V., \& Stocken, P. C. (2011). Managerial Reporting, Overconfidence, and Litigation Risk. Journal of Accounting and Economics, United States.

Mendes, C. A., Rodrigues, L. L., \& Esteban, L. P. (2012). Evidence of earnings management using accruals as a measure of accounting discretion. Tékhne, 10(1), 3-14.

Moradi, M., Salehi, M., \& Erfanian, Z. (2010). A Study of the Effect of Financial Leverage on Earnings Response Coefficient through out Income Approach: Iranian Evidence. International Review of Accounting, Banking and Finance, 2(2), 104-116.

Myers, S. C. (1984). The capital structure puzzle. The journal of finance, 39(3), 574-592.

Naftalia, V. C., \& Marsono, M. (2013). Pengaruh Leverage Terhadap Manajemen Laba Dengan Corporate Governance Sebagai Variabel Pemoderasi (Doctoral dissertation, Fakultas Ekonomika dan Bisnis).

Scott, W. R. (2012). Financial Accounting Theory 6th edition'. NY: Pearson Prentice Hall.

Rafiee, S. Z., Rafiee, S. Z., \& Heidarpoor, F. (2014). The effective factors of financial information quality in listed companies on Tehran Stock Exchange. International Journal of Accounting and Financial Reporting, 4(2), 201.

Suaryana, A. (2005). Pengaruh komite audit terhadap kualitas laba. Jurnal Ilmiah Akuntansi dan Bisnis.

Zamri, N., Rahman, R. A., \& Isa, N. S. M. (2013). The impact of leverage on real earnings management. Procedia Economics and Finance, 7, 86-95. 